\title{
Diversity Issues in Academic Reform
}

\author{
George B. Cunningham \\ Texas A\&M University
}

\begin{abstract}
The purpose of this paper was to provide a response to the Petr and McArdle (2012) and Paskus (2012) papers. The author suggests that academic reform should be couched within broader diversity issues affecting intercollegiate athletics, with a particular emphasis on race, social class, and the ability to implement reforms. Implications and conclusions are discussed.
\end{abstract}

I appreciate the opportunity to react to the papers presented by Petr and McArdle (2012) and Paskus (2012). In reviewing their work, I am struck by the shear depth of analysis and examination in which they engaged. Their overview of more than 100 years of academic reform is enlightening and their statistical analyses impressive. Indeed, all of this made the prospects of reacting to their work a bit unsettling. They, for instance, have been immersed in these data and the practice of academic reforms for decades. I, on the other hand, focus on diversity issues, not necessarily academic reform. And, given that I am more likely to equate APR with "annual percentage rate" than I am with "academic progress rate," I generally seek values as close to zero as possible, not greater than 930. As I delved deeper into their work, I kept wanting to follow Abraham Lincoln's advice: "It is better to remain silent and be thought a fool than to open one's mouth and remove all doubt." So, I was stuck with one of two prospects: stop here and present the shortest reaction in history, or think about how my work might relate to theirs and speak on that topic. Ultimately, I chose to adopt the latter. In doing so, I focus the intersection of academic reform with diversity issues, with a particular emphasis on social class and race.

\section{Diversity Issues in Academic Reform}

The intersection of diversity issues with academic matters is anything but a new endeavor. Federal graduation rate data, for instance, allow for examination of differences based on race, gender, and race-by-gender interactions. Indeed, perhaps because of this reporting structure, the National Collegiate Athletic Association (NCAA) has long remained cognizant of potential differences in educational success based on these diversity dimensions. Petr and McArdle (2012) and Paskus (2012) also highlight diversity issues in their analyses of the NCAA's academic reforms. Specifically, they note that: 
- Racial minority and low-income students are more likely than their peers to see athletics as a doorway to a college education; yet, academic reforms potentially hurt these persons the most.

- Graduation rates vary based on demographic characteristics. Across virtually all groups, student athletes graduate at higher rates than their peers in the student body. However, Whites graduate at meaningfully higher rates than do racial minorities, and this pattern holds for women and men.

- Improvement in student athlete academic performance is uneven across university contexts. Specifically, schools with large budgets and prestigious athletic programs are more likely to improve than are low-resource institutions, such as Historically Black Colleges and Universities (HBCUs).

I analyze each of these points in the remaining space.

\section{Social Class, Race, and Access to College}

I agree with Petr and McArdle (2012) and Paskus (2012) in their assertions that the poor and racial minorities are more likely to perceive athletics as the gateway to a college education than are more affluent or White individuals. But, in following other scholars (Edwards, 2011; Harrison, 2011; Hodge, Harrison, Burden, \& Dixson, 2008), I am not necessarily sure this is a good thing. Certainly participation in organized sport has many potential benefits: from a functionalist perspective, these include character development, refinement of athletic skills, social capital, and future opportunities (both academic- and sport-related), among others. But, the over-emphasis on athletics also serves to thwart poor and racial minority athletes' progress in other areas of their lives (see also Adler \& Adler, 1991). As a result, they are likely to bypass other educational prospects and learning experiences for the lure of "making it" through the athletic arena. Wiggins (2011) summarizes this nicely in noting:

In spite of the continued warnings over the years...regarding the danger of African American athletes viewing their bodies as their only resume and that individual success in sport is not a satisfactory solution to the problem of discrimination, the consolidation of power in a white elite has convinced lower class African Americans in particular, and others lacking power and available resources, that permanent social change is possible and that participation in sport and other forms of entertainment will result in both short and long term benefits. It is why warnings about the over dependence on sport are not heard by many economically challenged African American families who are not usually making a choice between professional athletics or education but rather a choice among professional athletics or being a blue-collar worker or living a life in the underworld. (p. 34)

I also concur with the authors' assertions that racial minority and poor students are more likely to be adversely affected by academic reforms (Paskus, 2012; Petr $\&$ McArdle, 2012). Certainly there are factors outside the purview of the NCAA contributing to this. Lott (2002; Lott \& Bullock, 2007), for instance, has noted that the educational system in the US is designed and financed in such a way that it privileges dominant, wealthy, power-holding individuals - a practice she refers to 
as institutional distancing. As a result of this form of classism, students from poor households are less likely to finish high school (Bullock, 2004) or college (Brooks, 2005) than are their wealthy peers. In fact, just $5 \%$ of students from families earning less than $\$ 35,000$ a year will complete college before turning 24 ; strikingly, the proportion rises to $50 \%$ for students from families earning $\$ 90,000$ or more annually (Brooks, 2005). Given the confluence of race and social class, many of these same patterns affect racial minorities.

That said, I am troubled by academic reforms that negatively impact a particular group. A number of others also note this disconnect, none of whom are perhaps more salient to me than John Thompson, the former men's basketball coach at Georgetown University. Indelibly marked on my mind is the image of Thompson leaving the court before the Georgetown $v$. Boston College game as a way of protesting the inequalities and unfairness of Proposition 42. Reforms such as Proposition 42, and others passed since then, are frequently painted as color-blind, race-neutral efforts aimed at improving the academic experiences of all athletes, but some scholars reject that position. For instance, Shropshire (1997), in adopting a critical race theory perspective, noted that such perspectives fail to consider the historical, systemic nature of racism and contends that many academic reforms in the NCAA reinforce negative stereotypes and negatively impact African Americans. Donnor (2005) has advanced similar arguments.

\section{Race and Graduation Rates}

Petr and McArdle (2012) and Paskus (2012) also note differences in federal graduation rates and graduation success rates. For students beginning school in the 2004-2005 academic year, African American, Latino, and Native American student athletes all graduated at higher rates than peers in the general student body. Nevertheless, there continue to be meaningful racial gaps in the graduation rates of student athletes, with racial minorities graduating less frequently than Whites. These differences remain even when using the NCAA's preferred graduation success rate (GSR).

In addition to examination of graduation rates, I submit that more attention needs to be devoted to potential racial differences in the educational experiences of student athletes. My friend and colleague at Texas A\&M, Dr. John Singer, has noted on several occasions that graduation is not the same as education. He is not necessarily only pointing to the definitions of the terms, as clearly the constructs differ in meaning. Rather, Dr. Singer has suggested to me and argued elsewhere (e.g., Singer, 2008) that while earning a college education is an important antecedent of life success, one should not necessarily assume that people who graduate have received a quality education or that their experiences during their college years were positive or of high quality. Rather, he and others have shown African American athletes routinely have much poorer college experiences than do their contemporaries. Specifically, researchers adopting both qualitative and quantitative methodologies across a variety of contexts have demonstrated African Americans are more likely than their White peers to: (a) face negative stereotypes about their intellectual abilities (Sailes, 1993); (b) have others presume they are only in college because of their athletic talents (something true for African American athletes 
and nonathletes alike; Harrison, Sailes, Rotich, \& Bimper, 2011); (c) be clustered into a limited range of majors (Singer, 2005); (d) feel exploited and singled out by their coaches and other athletic department staff (Singer, 2005); and (e) experience feelings of "being different" and "otherness" relative to others on campus (Carter \& Hart, 2010). These experiences are coupled with the prejudice and discrimination persons of color experience on primarily White college campuses (e.g., Lawrence, 2004).

To be sure, graduation success is important and a strong predictor of career income and unemployment. According to the Bureau of Labor Statistics, in 2010 persons with a bachelor's degree earned $65 \%$ more than those with a high school diploma and no college experience (\$1038 and \$626 per week, respectively). Furthermore, African Americans who do not attend college are nearly twice as likely to be unemployed compared with African Americans with a college degree (14.0 and 7.3 in 2009, respectively). But as important as graduation success is, it does not tell the whole story nor is it the only measure of academic success. As a datadrive entity, I encourage the NCAA to consider conducting large scale, theoretically based studies aimed at better teasing out some of the issues previously identified.

\section{Ability to Reform}

Finally, Petr and McArdle (2012) and Paskus (2012) note team improvements in APR are uneven, as teams at schools with large budgets and prestigious athletic programs are better equipped to make the changes needed for improvement. Their findings are consistent with research showing athletic department budget size is positively associated with the sophistication of the department's human resource system (Dixon, Noe, \& Pastore, 2008) and its overall athletic success (Cunningham, 2003). Furthermore, given that successful programs are more likely to generate the external donations and revenues needed to sustain this sophistication (Stinson \& Howard, 2007, 2008), the association between athletic department prestige and the ability to address human resource concerns is likely a continuous one.

What is disconcerting to me, though, is the other side of this relationship: schools with few resources and that do not have prestigious programs are least capable of implementing the reforms needed to realize APR improvements. Given the aforementioned relationship between prestige and revenue generation from external sources, these less prominent athletic departments are forced to rely on other financial resources, such as institutional support-a financial well that is increasingly dry (for more information on institutional support, see Fulks, 2011). As a result, they continue to be penalized, while the better-resourced schools do not face such restrictions and therefore continue to thrive.

Thus, the current system appears to create a self-perpetuating cycle of haves and have-nots, privileging athletic departments situated in primarily White, researchintensive institutions while penalizing departments situated in institutions with few financial resources, like many HBCUs. I appreciate that these reforms are, relatively speaking, new and the data are still emerging. Petr and McArdle (2012) and Paskus (2012) have also noted academic reform in the NCAA has been firmly grounded in research and data. Thus, given that the data illustrate this troubling trend, I hope and suspect that new solutions will be available to remedy the situation. 


\section{Conclusions}

To close, I want to again note that I appreciate being asked to respond to Petr and McArdle's (2012) and Paskus' (2012) comments. Their exhaustive and impressive analysis shows that, especially recently, the NCAA has used empirical data to devise strategies aimed at improving student athletes' graduation success. And, in many ways, these reforms have been successful. However, as I have noted elsewhere, "diversity has been, and will continue to be, one of the most important issues managers encounter" (Cunningham, 2011, p. xvii). This is clearly the case in the current discussion, as social class and race are uniquely intertwined with academic reform efforts. As the NCAA moves forward with further developments, my hope is that they remain mindful of (a) how academic reforms have the potential to differentially impact certain groups, (b) the entire educational experience of the student athlete, and (c) a system that creates perpetuates institutional forms of classism at the department level.

\section{References}

Adler, P.A., \& Adler, P. (1991). Backboards and blackboards: College athletes and role engulfment. New York: Columbia University Press.

Brooks, D. (2005, October). Pillars of cultural capital. New York Times. Retrieved September 4, 2009, from http://select.nytimes.com/2005/10/06/opinion/06brooks.html?_r=1.

Bullock, H.E. (2004). Class diversity in the workplace. In M.S. Stockdale \& F.J. Crosby (Eds.), The psychology and management of workplace diversity (pp. 226-242). Malden, MA: Blackwell.

Carter, A.R., \& Hart, A. (2010). Perspectives of mentoring: The Black female student-athlete. Sport Management Review, 13, 382-394. doi:10.1016/j.smr.2010.01.003

Cunningham, G.B. (2003). Human resources as sources of competitive advantage: A resource-based view of the athletic department. Applied Research in Coaching and Athletics Annual, 18, 37-58.

Cunningham, G.B. (2011). Diversity in sport organizations (2nd ed.). Scottsdale, AZ: Holcomb-Hathaway.

Dixon, M.A., Noe, R.A., \& Pastore, D.L. (2008). Human resource management systems and organizational effectiveness in non-profit sport organizations: A multilevel approach. International Journal of Sport Management, 9, 22-45.

Donnor, J.K. (2005). Towards an interest-convergence in the education of African-American football student athletes in major college sports. Race, Ethnicity and Education, 8, 45-67. doi:10.1080/1361332052000340999

Edwards, H. (2011). Transformational developments at the interface of race, sport, and the collegiate arms race in the age of globalization. Journal of Intercollegiate Sport, 4, $18-31$.

Fulks, D.L. (2011). Revenues and expenses: 2004-2010 NCAA Division I intercollegiate athletic programs report. Indianapolis, IN: National Collegiate Athletic Association.

Harrison, L., Jr. (2011). Athletes' rights and justice issues: It's not business, it's personal. Journal of Intercollegiate Sport, 4, 14-17.

Harrison, L., Jr., Sailes, G., Rotich, W.K., \& Bimper, A.Y., Jr. (2011). Living the dream or awakening from the nightmare: Race and athletic identity. Race, Ethnicity and Education, 14, 91-103. doi:10.1080/13613324.2011.531982

Hodge, S.R., Harrison, L., Jr., Burden, J.W., Jr., \& Dixson, A.D. (2008). Brown in Black and White-then and now: A question of educating or sporting African 
American males in America. The American Behavioral Scientist, 51, 928-952. doi:10.1177/0002764207311998

Lawrence, S.M. (2004). African American athletes' experiences of race in sport. International Review for the Sociology of Sport, 40, 99-110. doi:10.1177/1012690205052171

Lott, B. (2002). Cognitive and behavioral distancing from the poor. The American Psychologist, 57, 100-110. PubMed doi:10.1037/0003-066X.57.2.100

Lott, B., \& Bullock, H.E. (2007). Psychology and economic injustice: Personal, professional, and political intersections. Washington, DC: American Psychological Association.

Paskus, T. (2012). A summary and commentary on the quantitative results of current NCAA academic reforms. Journal of Intercollegiate Athletics, 5, 41-53.

Petr, T.A., \& McArdle, J.J. (2012). Academic research and reform: A history of the empirical basis for NCAA academic policy. Journal of Intercollegiate Sports, 5, $27-41$.

Sailes, G.A. (1993). An investigation of campus typecasts: The myth of black superiority and the dumb jock stereotype. Sociology of Sport Journal, 10, 88-97.

Singer, J.N. (2005). Understanding racism through the eyes of African American male studentathletes. Race, Ethnicity and Education, 8, 365-386. doi:10.1080/13613320500323963

Singer, J.N. (2008). Benefits and detriments of African American male athletes' participation in a big-time college football program. International Review for the Sociology of Sport, 43, 399-408. doi:10.1177/1012690208099874

Shropshire, K.L. (1997). Colorblind propositions: Race, the SAT, \& the NCAA. Stanford Law \& Policy Review, 8(1), 141-152.

Stinson, J.L., \& Howard, D.R. (2007). Athletic success and private giving to athletic and academic programs at NCAA institutions. Journal of Sport Management, 21, 237-266.

Stinson, J.L., \& Howard, D.R. (2008). Winning does matter: Patterns in private giving to athletic and academic programs at NCAA Division I-AA and I-AAA institutions. Sport Management Review, 11, 1-20. doi:10.1016/S1441-3523(08)70101-3

Wiggins, D.K. (2011). Farewell to sport: The decline of the African American athlete during the age of the collegiate arms race and globalization. Journal of Intercollegiate Sport, 4, 32-37. 